\title{
Integrating EAP with EOP: An Eclectic Approach toward the Instruction of Iranian Engineering Undergraduates
}

\author{
Somayeh Biparva Haghighi ${ }^{1}$ \\ ${ }^{1}$ Shahid Chamran University of Ahvaz, Iran \\ Correspondence: Somayeh Biparva, Language Department, School of Literature and Humanities, Shahid \\ Chamran University of Ahvaz, Iran. Tel: 98-611-333-4458. E-mail: sbh18370@yahoo.com
}

Received: May 5, 2012 Accepted: May 21, 2012 Online Published: July 22, 2012

doi:10.5539/ies.v5n4p257 URL: http://dx.doi.org/10.5539/ies.v5n4p257

\begin{abstract}
It is commonly observed that training in English for Academic Purposes (EAP) cannot successfully guarantee skills in English for Occupational Purposes (EOP). This study proposes an EOP-oriented course in an academic setting. It is designed to equip undergraduate students of engineering with general skills for EOP practices to meet students' future needs after graduation. EOP skills mainly include report reading/writing and development of technical vocabulary knowledge. A main feature of this EOP-oriented course is that it does not rely on any one single approach to syllabus design, but takes an eclectic approach by drawing on elements from a task- based syllabus, a text-based syllabus, and a content-based syllabus for the design of the program.
\end{abstract}

Keywords: EAP, EOP, report reading/writing, task-based, content-based, and text-based syllabuses

\section{Introduction}

Until fairly recently, most syllabus designers started their programs by drawing up lists of grammatical, phonological, and vocabulary items which were then graded according to difficulty and usefulness. The role of the learner was seen as gaining mastery over the grammatical, phonological, and vocabulary items.

During 1970s, as Nunan (1994) describes, communicative views of language teaching began to be incorporated into syllabus design. Syllabuses began to appear in which content was specified, not only in terms of the grammatical elements but also the functional skills that the students would need to communicate successfully with (p. 11).

This movement led in part to the development of English for Specific Purposes (ESP). Many different syllabus types have been proposed for ESP instruction: structural, situational, functional-notional, task-based, text-based, and content-based (Hutchinson \& Waters, 1987; Jordan, 1997; Watson, 2003). The type of syllabus which is implemented is noticeably dependent on a previously conducted need analyses which may not only examine the target situation, i.e., what learners are required to do, but also consider learning needs, i.e., how learners are best motivated to acquire the language and skills revealed through the target situation analysis. However, in reality, many syllabuses constructed by course instructors may not neatly fall into one specific category, but to address students' needs they should draw on aspects of two or three different syllabus types. Introspections across the students' need analyses and learning preferences in this study resulted in two key research questions for the succeeding directions of the course:

1) What are ESP students' language needs?

2) Are there any significant differences between the two groups in the post-test in relation to the eclectic approach?

\subsection{Approaches to Syllabus Design}

To find out what linguistic content is generated and practiced in educational context, it is necessary to review the adopted approaches to syllabus design. A task-based syllabus is concerned with purposeful activities which learners might be expected to engage in real-life situations. As Ellis (2003) points out, this type of syllabus also puts emphasis on meaning and communication, where students are primarily "users" rather than "learners" of the language. Learners may switch their attention to form when performing a task, but the code is seen as peripheral to the focus on meaning. These key features are encapsulated in Skehan's (1996, p. 50) definition of task as “an 
activity in which: meaning is primary; there is some sort of relationship to the real world; task completion has some priority; and the assessment of task performance is in terms of task outcome." While the importance of form is recognized in the task-based approach, Littlewood (2004) proposes a model which allows for different degrees of focus on form or meaning depending on the teaching purposes.

In a text-based syllabus, as its name suggests, the content for such syllabus is based on whole texts. Another key element of this type of syllabus, as defined by Feez (2002), is that this content is "selected in relation to learner needs and the social contexts which learners wish to access" (p. 3). This approach to syllabus design draws on the Australian tradition of genre, which emphasizes the social contexts in which genres are constructed, and how language is used in these contexts. In this approach, the pedagogy is very much influenced by the concept of empowering disadvantaged learners to make progress through mastery of key genres, i.e., those genres necessary for progress in the workplace. The text-based syllabus also has aspects in common with the task-based approach in that it sees language as a functional rather than formal artifact, to be used as a resource for meaning-making and for achieving purposeful goals. In fact, proponents of this type of syllabus are keen to point out that it can be considered as a type of mixed syllabus.

Brinton, Snow, and Wesche (1989) introduce and comment on three well-known models of Content-Based Instruction (CBI): thematic, sheltered, and adjunct, which are all designed to help students with their university content courses. However, they differ in their orientations towards language and content: "in the theme-based model, it is the primary aim of the course to help students develop second language competence, while in the sheltered model the primary aim is to help students master content material” (p. 18). In the adjunct model, the language course is linked with a content course and both share the same content base. With this shared focus on content, the rationale behind the adjunct model is that "the linked courses will assist students in developing academic coping strategies and cognitive skills which will transfer from one discipline to another" (p. 17). In this type of syllabus, language is also seen as functional and is integrated with the teaching of content. Moreover, Pally (1999) emphasizes the "sustained" nature of CBI, putting forward the case that students can only develop and work on the rhetorical and argumentative skills associated with particular subject disciplines through sustained, incremental practice over a period of time.

\section{Methodology}

\subsection{Participants and Settings}

The course described in this article was a one-semester course of 102 contact hours for 120 first-year undergraduate engineering students from two EAP classes at Shahid Chamran University of Ahvaz, Iran. Their age range was eighteen to twenty and the research was conducted in the 2010-2011 education years; the classes were co-educational and held twice a week. The sample population was divided into the experimental group $(\mathrm{N}=60)$, who were exposed to the needs-based syllabus and the control group $(\mathrm{N}=60)$, who were presented with the usual teaching approach for an academic semester. Their level of English language proficiency ranged from beginner (21.3\%) to upper intermediate (62.4\%) and advanced (16.3\%) for the experimental group as suggested by their scores in the Oxford Placement Test (OPT); the students in the control group were identified as beginners (23.2\%), upper intermediate (59.7\%), and advanced (17.1\%) respectively. Evidently, the two groups established nearly an identical basis for the special design of this study.

\subsection{Materials: Need-Based Syllabus Design}

In considering needs and goals, the researcher noted that lecturer's syllabus and the learner's syllabus or 'agenda' might differ. Consequently, the researcher devised the process of needs analysis to involve lecturers and learners in exchanging information so that the agendas of the lecturer and the learner could be more aligned. This happened in two ways. In the first place, information provided by learners through need analyses guided the selection of the content and learning activities. Secondly, by providing learners with detailed information about goals, objectives, and learning activities, learners increased their appreciation and acceptance of the leaning experience they were undertaking or about to undertake. Learners perhaps had different goals from those of the lecturer simply because they had not been informed in any meaningful way what the course goals were.

To obtain the students' major goals and learning preferences, a modified model of Willing's (1988) questionnaire was applied. The questionnaire asked students to rate a series of statements according to how accurately they reflected the learners' attitudes and preferences (see Appendix 1).

According to the students proficiency scores, engineering students proved to be competent enough in general English so that the lecturer confidently focused the classes attention on general EAP tasks: to write an academic paper using secondary sources and be ready to read their peers' written reports as well. Next, more specific EAP 
areas were covered, such as the writing of their projects reports, moving to a more EOP focus in the latter part of the semester. In this component, students were trained to write persuasively in listing, temporal sequence, compare-contrast, problem-solution, and cause-effect rhetorical patterns, where they were expected to present ideas, convey events in terms of passage of time, describe similarities or differences, and consider effects or results of events (Appendix 2).

\subsection{Procedures}

As the experimental group of students marked their needs and learning preferences through the questionnaire (Appendix 1), the researcher could decide on how to integrate the EAP course with EOP essentials and finally how to appraise students' achievements. In the following sections, I describe how EOP-oriented instruction of writing skills was presented through the integration of task-based, text-based and CBI-based syllabuses.

\subsubsection{Task-based Perspective}

The main components of the group research project in which students carried out research on a particular topic in a group of six students produced the first written report to be followed and completed in next phases; ideas for conducting writing activities at this level were given by Grabe \& Kaplan, (1996, p. 344-345).

1) Choose an area for investigation;

2) Identify a problem/need/demand within this area;

3) Collect data from primary sources (i.e., interviews, observations, survey questionnaires) and secondary sources (i.e., print material, Internet);

4) Analyze and interpret the data collected from secondary and primary sources;

5) Make suggestions for future action.

Students were encouraged to choose areas for investigation related to their own subject disciplines, which tended to be university-based. For example, students chose to investigate issues such as inadequacy in engineering equipments of university, the current level of technical knowledge in new branches of engineering, laboratory safety practices, and so on. However, students were also allowed to research non-science issues for some reasons (i.e., some engineering students take up posts in the service fields rather than technical fields).

In order to collect their data, students were required to communicate and interact with people in a workplace situation. Students were also writing to a real audience, that was either their lectures or peers. Another advantage of this simulation was that it opened the eyes of the students to the real workplace situation and sensitized them to the fact that certain problematic issues might be more difficult to solve than originally anticipated because of various constraints, e.g. budget limitations. Also, it was found that allowing students to choose their own topic (with guidance from the lecturer) was an important motivational factor. While not wholly CBI-based, in the traditional sense, this communication skills course did share features in common with certain CBI approaches, as described in the following section.

\subsubsection{Content-based Perspective}

The program reported on in this article in part adopted a CBI approach to workplace communication taking place in an academic setting. The project topics were either of a general interest nature or related to students' subject discipline; in both cases, the input material for the course was CBI-oriented.

The course made use of authentic environmental reports, which were related to the science students' disciplines, to familiarize them with the basic principles of writing an analytical report using content-based material. This course thus had most in common with the thematic type of CBI as it was content-based in orientation, but textand language-based in its main focus. Another important feature of the course was that it took up Pally's (1999) assertion that CBI is best delivered through sustained instruction.

\subsubsection{Text-based Perspective}

Students worked on the project throughout the whole 17 -week semester, first spending time on refining the objective and scope of their project topic, and then producing an outline and refining a draft before writing up the final project report. In the last phase, which was text-based aspect of the course, students were obliged to organize their data through the five stages outlined in Feez (2002, p. 28) as is shown in the Figure 1 below. 


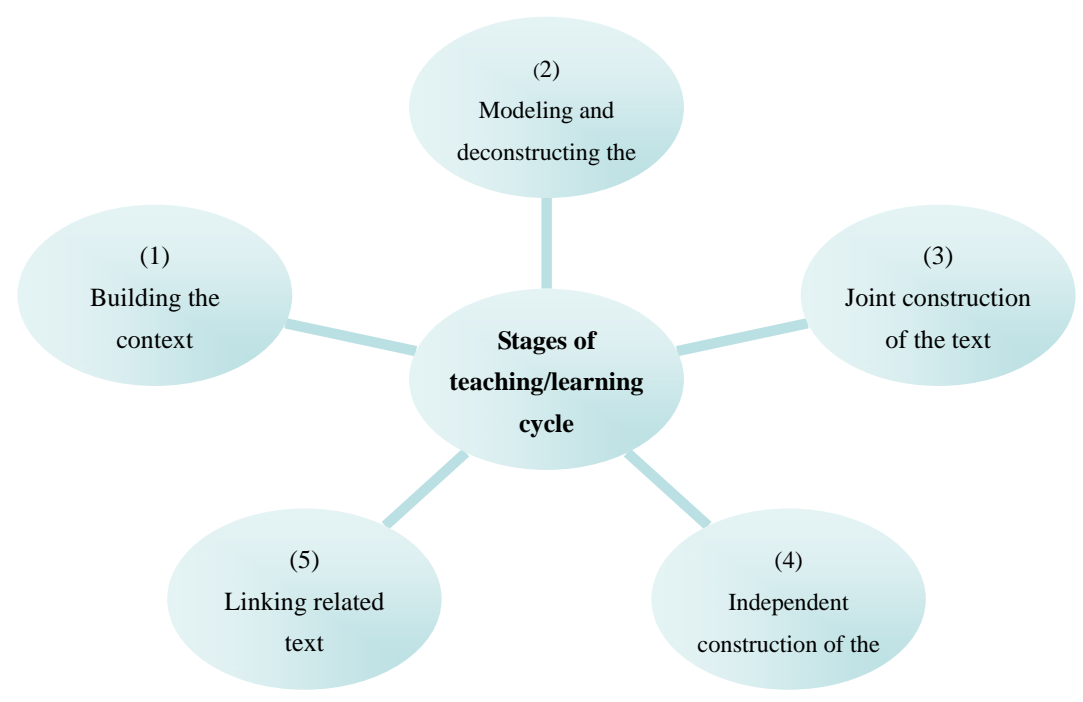

Figure 1. Stages of the teaching/learning cycle (Feez, 2002)

It has been noted in the previous section that the input material is content-based in that it consists of authentic reports. The report discussed here was about the current level of technical engineering knowledge, with recommendations for improvement of lectures' instruction and augmentation of students' exposure to reading/writing about modern topics. In the 'building the context' stage, students were introduced to the communicative purpose of the report.

In the second stage 'modeling and deconstructing the text' students learnt their needed organizational pattern and lexico-grammatical features of the workplace report. As mentioned in section 2.2, students were obliged to arrange their materials through an appropriate rhetorical pattern. Students were trained to probing their subject by asking a series of questions that could help them to order the material by following an effective organization (Appendix 2).

In stage 3 of Feez' (2002) model 'joint construction of the text,' practice was given to students in constructing different sections of a report according to the content and language features. Here, students' attention was drawn to the overall coherence of the report relating to the problem-solution pattern as this was a weakness in students' writing. In stage 4 'independent construction of the text,' students worked on their own group project reports described previously under task-based perspective, paying particular attention to the specific socio-cultural context in which they were writing. In stage 5, students were instructed to qualify their writing through the use of prepositions, associate discourse markers, and logical connectors to make their academic papers as unified as possible.

\subsection{Post-instruction Assessment}

The focus of the post-test was to assess reading/writing skills and technical vocabulary development through integration of task-based, content-based, and text-based perspectives, all designed with the intention of addressing students' future needs. More specifically, the tasks reflected real-life professional and academic situations as closely as possible. The idea of 'authenticity of task' (Douglas, 2000; Bowles, 2006; Chostelidou, 2011) was crucial throughout the test. The starting point for any task was a purpose of some kind for which a language user in the real professional or academic world would actually read or write. Similarly, the texts used were selected in order to provide appropriate subject-specific input in line with the demands of such tasks. The results were analyzed qualitatively and quantitatively using descriptive statistical procedures including independent samples t-test to examine whether significant differences exist between the two groups of learners regarding their final awareness resulting from the eclectic treatment. 
Table 1. Post-test format (total score=100)

\begin{tabular}{|c|c|c|c|}
\hline Skill assessed & $\begin{array}{l}\text { Number of } \\
\text { tasks }\end{array}$ & Timing & Weighting \\
\hline Writing & 1 & $30 \mathrm{~min}$ & $40 \%$ \\
\hline Reading & 3 & $30 \mathrm{~min}$ & $40 \%$ \\
\hline Vocabulary & 3 & $20 \mathrm{~min}$ & $20 \%$ \\
\hline
\end{tabular}

\section{Results}

\subsection{Need Analyses and Learning-style Preferences}

As it was noted in previous sections, by providing learners with detailed information about goals, objectives, and learning activities, learners increased their knowledge and understanding of the language skills they were about to undertake in future occupational situations. This awareness proved to be functional as the ten highest scored statements of the questionnaire of learning-style preferences (Appendix 1) were indicative of students' future occupational needs:

Table 2. The result of need analyses questionnaire devised by Willing (1988)

\begin{tabular}{|c|c|}
\hline 10 highest scored statements & $\begin{array}{l}\text { Percentage of } \\
\text { students }\end{array}$ \\
\hline I like the class draw on my future needs. & $87 \%$ \\
\hline I prefer to work on real data. & $85 \%$ \\
\hline $\begin{array}{l}\text { I welcome opportunities for language } \\
\text { practice. }\end{array}$ & $81 \%$ \\
\hline I like to learn technical words. & $80 \%$ \\
\hline $\begin{array}{l}\text { I like to write reports about my field of } \\
\text { study. }\end{array}$ & $76 \%$ \\
\hline I like to learn English by reading. & $72 \%$ \\
\hline $\begin{array}{l}\text { I prefer a class which adopts flexible } \\
\text { approaches to tasks. }\end{array}$ & $68 \%$ \\
\hline $\begin{array}{l}\text { I like to predict the outcome of my English } \\
\text { class. }\end{array}$ & $63 \%$ \\
\hline In class, I like to learn by conversation. & $59 \%$ \\
\hline $\begin{array}{l}\text { I like to use my English to watch films and } \\
\text { listen to music. }\end{array}$ & $56 \%$ \\
\hline
\end{tabular}

The researcher in this phase could manifestly apprehend students' authentic needs: to learn English while they were involved in realia such as reading technical passages and writing science-related reports.

\subsection{The Effect of the Eclectic Approach on the Outcome of the EOP Skills}

At the end of the semester, as the researcher could check the influence of EOP-oriented instruction through integration of task-based, content-based, and text-based perspectives, the post-test session was held. Here is the comparison of t-test results of the control and experimental groups. 
Table 3. The comparison of t-test results of the control and experimental groups

\begin{tabular}{lllll}
\hline \multicolumn{1}{c}{ Groups } & Skills & $\begin{array}{l}\text { Std. } \\
\text { Deviation }\end{array}$ & Mean & $\begin{array}{l}\text { Sig. } \\
\text { (2-tailed) }\end{array}$ \\
\hline $\begin{array}{l}\text { Control } \\
(\mathrm{N}=60)\end{array}$ & Writing & 3.57 & 18.63 & 0.040 \\
$\begin{array}{l}\text { (Total } \\
\text { score=100) }\end{array}$ & Reading & 4.78 & 21.35 & 0.042 \\
& Vocabulary & 2.87 & 14.91 & 0.218 \\
Experimental & Writing & 4.92 & 25.70 & 0.040 \\
& & & & \\
$\begin{array}{l}(\mathrm{N}=60) \\
(\text { Total }\end{array}$ & Reading & 5.78 & 26.15 & 0.042 \\
score=100) & & & & \\
& Vocabulary & 2.53 & 15.31 & 0.218 \\
\hline
\end{tabular}

*Mean is significant at 0.05 level $(\mathrm{p}<0.05)$

\section{Discussion: From Needs to Goals}

According to the results of the t-test and the value of mean scores (Table 3), evidently the most significant difference between the outcomes of EOP-based instruction of this study belongs to the domain of writing skills. Academic writing has been considered as the most challenging skill to be mastered; yet, as Ibrahim and Nambiar (2010) states, it has to be mastered quickly as a mark of scholarship in today's world.

As Wong \& Wu (1998) predict, the report writing module familiarized students to the general principles of writing a technical report in accordance with instructed organizational patterns and their associate discourse markers. This appeared to be a logical extension of language programs for EAP students for various reasons (p. 11). Most importantly, report writing was specifically highlighted by students in the needs analyses as deserving attention. Secondly, the analytical nature of academic writing, in which alternative solutions were often put forward and their advantages and disadvantages discussed, would also be an extension of argumentation students were introduced in other linked courses. Thirdly, a general report writing module bridged the gap between EAP-oriented report writing and final undergraduate project reports, and more EOP-oriented report writing, as all these reports basically followed a similar organizational structure.

The second EOP-based skill which was studied in this paper was reading technical reports. There is still a meaningful difference between the outcomes of experimental group compared to that of the control (though it must be noted that the difference between the two groups was more significant in the case of academic writing skills). Still in the case of academic reading comprehension, the experimental students were privileged and that was most likely due to their metacognitive knowledge of text patterns and their associate signal words since reading is viewed as decoding process of reconstructing the author's intended meaning via recognizing the organizational patterns and signal words, and building up a meaning from the text (Biparva \& Shooshtari, 2012). Sharp (2002) also concurs that as readers interact with the text to construct meaning, their comprehension is facilitated when they organize their thinking in a manner similar to that used by the author.

There is still another feature of the EOP instruction to be studied: development of technical vocabulary. According to the post-test results (table 3), although there is still a difference between the mean values at this stage, the two groups demonstrated nearly the same technical vocabulary efficacy. Such equal competency might allude to the fact that planned instruction in domains of reading/writing skills appeared to be essential while vocabulary was of a nature that could be self-studied and also followed up even in the regular control class.

\section{Conclusion}

This article described an EOP-oriented course which drew on elements of three different, but somewhat related approaches to syllabus design: task-based, content-based and text-based. Watson (2003, p. 154) has raised the point that much previous work in EAP has focused more on the content of teaching than on the methodology, and calls for a more balanced approach where students' learning needs, i.e., "the how" are given equal weighting 
to their language needs, i.e., "the what". It was attempted that the course described in this article led the way towards attaining a more balanced approach in that the language learning needs by the content-based, text-based, and task-based elements.

\section{Acknowledgment}

I would like to express my special gratitude and thanks to my professors at Shahid Chamran University of Ahvaz whose support has always been my source of strength and inspiration.

\section{References}

Biparva, S. H., \& Shooshtari, Z. G. (2012). Mining Perspective and Rhetorical Patterns in Reading for Revision: A Case Study of Iranian Intermediate EFL Readers. Theory and Practice in Language Studies, 2(5), 1080-1089. http://dx.doi.org/10.4304/tpls.2.5.1080-1089

Bowles, H. (2006). Bridging the gap between conversation analysis and ESP: an applied study of the opening sequences of NS and NNS servicetelephone calls. English for Specific Purposes, 25(3), 332-357.

Brinton, M., Snow, M., \& Wesche, M. (1989). Content-based Second Language Instruction. Boston, MA: Heinle and Heinle.

Chostelidou, D. (2011). Needs-based course design: the impact of general English knowledge on the effectiveness of an ESP teaching intervention. Procedia Social and Behavioral Sciences, 15, 403-409. http://dx.doi.org/10.1016/j.sbspro.2011.03.112

Douglas, D. (2000). Assessing language for specific purposes. Cambridge: Cambridge University Press.

Ellis, R. (2003). Task-based language learning and teaching. Oxford: OUP.

Feez, S. (2002). Text-based syllabus design. NCELTR: Macquarie University.

Grabe, W., \& Kaplan, R. (1996). Theory and Practice of Writing. London: Longman.

Hutchinson, A., \& Waters, B. (1987). English for Specific Purposes. Cambridge: Cambridge University Press.

Ibrahim, N., \& Nambiar, R. M. K. (2010). Writing in foreign lands: the case of postgraduate international students and the introductory sections of a project paper. Procedia Social and Behavioral Sciences, 18, 626-632. http://dx.doi.org/10.1016/j.sbspro.2011.05.043

Jordan, R. R. (1997). English for Academic Purposes. Cambridge: Cambridge University Press.

Littlewood, B. (2004). The task-based approach: Some questions and suggestions. ELT Journal, 58(4), 319-326.

Mebarki, Z. (2011). Factors underlying the reading performance of Algerian microbiology students. Procedia -Social and Behavioral Sciences, 29, 1759 - 1768. http://dx.doi.org/10.1016/j.sbspro.2011.11.422

Nunan, D. (1994). Syllabus Design. Oxford. OUP.

Pally, M. (1999). Sustained Content Teaching in Academic ESL/EFL. Boston, MA: Houghton Mifflin.

Robinson, P. (1991). ESP Today. London: Prentice Hall.

Sharp, A. (2002). Chinese L1 Schoolchildren Reading in English: The Effects of Rhetorical Patterns. Reading in a Foreign Language, 14(2), 1-20.

Skehan, P. (1996). A framework for the implementation of task-based instruction. Applied Linguistics, 17(1), 38-62.

Watson T. R. (2003). EAP or TEAP? Journal of English for Academic Purposes, 2(2), 147-156.

Willing, K. (1988). Learning Styles in Adult Migrant Education. Adelaide: National Curriculum Resource Centre.

Wong, K., \& Wu, L. (1998). English Language Needs Analysis. Hong Kong: Hong Kong University of Science and Technology, Language Center. 


\section{Appendix}

Appendix 1. Questionnaire of need analysis and learning-style preferences: adopted from Willing's (1988).

Students rated a series of statements according to how accurately they reflected the learners' own attitudes and preferences. Learners were asked to respond according to the following key: 1= "No"; 2= "A little"; 3="Good"; $4=$ ="Best". The statements to which the students were asked to response are as follows

1) I like to practice the sounds and pronunciation.

1234

2) I like the teacher to tell all my mistakes.

1234

3) In class, I like to learn by conversation.

1234

4) I like the teacher to explain everything to us.

1234

5) I like to promote my attention toward meaning.

1234

6) I like the class draw on my future needs.

1234

7) I prefer a class which adopts flexible approaches to tasks.

1234

8) I like the class problem be worked on by learners.

1234

9) I like to use English while solving English tasks.

10) I like to study grammar.

1234

11) I like to learn English in small groups.

12) I welcome opportunities for language practice.

1234

13) I like to share information with my classmates.

14) I like to predict the outcome of my English class.

15) I like a challenging but not a competing class.

16) I like to learn English with the whole class.

17) I like to have a chance to influence the purpose of instruction. 1234

18) I prefer to work on real data.

1234

19) I like to study English by myself.

1234

20) I like to learn English by reading.

21) I like to write reports about my field of study.

22) I like to learn technical words.

23) I like to receive feedback.

1234

24) I like to learn how to learn English by myself.

25) I like to use my English to watch films and listen to music.

1234 
Appendix 2. Rhetorical patterns and associates discourse markers

\section{Text Structure Signal Questions \& Signal Words}

\begin{tabular}{|c|c|c|}
\hline Listing & $\begin{array}{l}\text { Compare and } \\
\text { Contrast }\end{array}$ & Sequence \\
\hline $\begin{array}{l}\text { A topic, idea, person, } \\
\text { place, or thing is } \\
\text { described by listing } \\
\text { its features, } \\
\text { characteristics, or } \\
\text { examples. }\end{array}$ & $\begin{array}{l}\text { Shows how two } \\
\text { or more things } \\
\text { are alike and/or } \\
\text { how they are } \\
\text { different. }\end{array}$ & $\begin{array}{l}\text { Describes items } \\
\text { or events in order } \\
\text { or tells the steps } \\
\text { to follow to do } \\
\text { something or } \\
\text { make something. }\end{array}$ \\
\hline
\end{tabular}

$\begin{array}{ll}\text { Problem } & \text { Cause and } \\ \text { and } & \text { Effect }\end{array}$

Solution

Tells about a Cause is why problem (and something sometimes says happened. why there is a Effect is what problem) then happened. gives one or (Sometimes the more possible effect is listed solutions. first.)

\section{Signal Questions}

What specific topic, person, idea, or thing is being described? How is it being described (what does it look like, how does it work, what does it do, etc.)? What is important to remember about it?

What things are being compared? In what ways are they alike? In what ways are they different?
What items, events, or steps are listed? Do they have to happen in this order? Do they always happen in this order?

\author{
What is the \\ problem? Why \\ is this a \\ problem? Is \\ anything being \\ done to try to \\ solve the \\ problem? What \\ can be done to \\ solve the \\ problem?
}

\section{Signal Words}

For instance
Such as...
To begin with
An example
To illustrate
Characteristics
*Look for the topic
word (or a synonym
or pronoun) to be
repeated

Same as Similar Alike As well as Not only...but also

Both

Instead of

Either...or

On the other

hand

Different from

As opposed to

First
Second
Next
Then
Before
After
Finally
Following
Not long after
Now
Soon

Question is... So Dilemma is... Because The puzzle is... Since To solve this... Therefore One answer is... If...then One reason for This led to the Reason why problem is... As a result May be due to Effect of Consequently For this reason 